COMMENTS AND DISCUSSIONS COMMENTAIRES ET DISCUSSIONS

\title{
A note on the theory of the hydraulic jump in a parabolic channel
}

\section{Note sur la théorie du ressaut hydraulique dans un canal parabolique}

In a recent article (La Houille Blanche, $\mathrm{n}^{\circ} 6$, December 1961) under the above title, BinnIE derived an equation for the conjugate depths of a hydraulic jump in a parabolic channel by introducing the initial Froude number $\mathscr{F}_{x}$ into an equation proposed by Argyropoulos in 1957. The writer would like to point out that an identical equation was presented by him in an article on the hydraulic jump in trapezoidal channels (Water Power, January 1961) as a particular case of the general equation for the conjugate depths in exponential channels:

$$
\mathscr{W}_{1}^{2}=\frac{n}{n+1} \frac{\left(d_{2} / d_{1}\right)^{n}\left[\left(d_{2} / d_{1}\right)^{n+1}-1\right]}{\left(d_{2} / d_{1}\right)^{n}-1}
$$

in which $n$ is the exponent in the equation relating the area and the depth:

$$
\mathrm{A}=\mathrm{K} d^{n}
$$

For a parabolic channel $n=1.5$ and equation (1) is reduced to equation (5) in Binnie's article or to equation (16) in the writer's article: The latter also gives a family of curves of $\left(d_{2} / d_{1}\right)$ for various values of the exponent $n$ the range of 1 to 2 .

A point to note is that for large values of $\left(d_{2} / d_{1}\right)$, or of $\mathscr{F}_{1}$, both $\left(d_{2} / d_{1}\right)^{n}$ and $\left(d_{2} / d_{1}\right)^{n+1}$
Sous ce titre, A. M. BinniE, dans un récent article (La Houille Blanche, $\mathrm{n}^{\circ} 6$, décembre 1961) a proposé une équation pour les profondeurs conjuguées d'un ressaut hydraulique dans un canal de section parabolique, en introduisant le nombre de Froude initial $\mathscr{H}_{1}$ dans l'équation donnée par Argyropoulos en 1957. L'auteur tient à signaler qu'il a présenté une équation identique dans un article sur le ressaut hydraulique en canaux trapézoïdaux (Water Power, janvier 1961), comme cas particulier de l'équation générale des profondeurs conjuguées dans les canaux exponentiels :

$$
\mathscr{G}_{1}^{2}=\frac{n}{n+1} \frac{\left(d_{2} / d_{1}\right)^{n}\left[\left(d_{2} / d_{1}\right)^{n+1}-1\right]}{\left(d_{2} / d_{1}\right)^{n}-1}
$$

où $n$ est l'exposant d'une équation reliant la surface et la profondeur :

$$
\mathrm{A}=\mathbf{K} d^{n}
$$

Pour un canal parabolique, $n=1,5$ et l'équation (1) se réduit à l'équation (5) de l'article de Binnie ou à l'équation (16) de l'article de l'auteur. Cette dernière procure aussi une famille de courbes de $\left(d_{2} / d_{1}\right)$ pour diverses valeurs de l'exposant $n$ comprises entre 1 et 2 .

Un point à signaler est que, pour des valeurs élevées de $\left(d_{2} / d_{1}\right)$, ou de $\mathscr{H}_{1},\left(d_{2} / d_{1}\right)^{n}$ et $\left(d_{2} / d_{1}\right)^{n+1}$ deviennent tous deux élevés par rapport à 1 , de 
become large in comparison to 1 so that equation (1) may be simplified into:

$$
\mathfrak{F}_{1}^{2}=\frac{n}{n+1}\left(\frac{d_{2}}{d_{1}}\right)^{n+1}
$$

which can be solved directly for the ratio $d_{2} / d_{1}$

$$
\frac{d_{2}}{d_{1}}=\left[\frac{n+1}{n} \mathscr{F}_{1}^{2}\right]^{1 / n+1)}
$$

For parabolic channels the equation becomes:

$$
\left(\frac{d_{2}}{d_{1}}\right)=\left(\frac{5}{3} \mathscr{F}_{1}^{2}\right)^{0,4}
$$

which may also be used as a first approximation to the more exact equation when the ratio $\left(d_{2} / d_{1}\right)$ is not large. sorte que l'équation (1) peut être simplifiée comme suit :

$$
\mathscr{g}_{1}^{2}=\frac{n}{n+1}\left(\frac{d_{2}}{d_{1}}\right)^{n+1}
$$

équation qui peut être résolue directement pour le rapport $d_{2} / d_{1}$ :

$$
\frac{d_{2}}{d_{1}}=\left[\frac{n+1}{n} \mathscr{\exists}_{1}^{2}\right]^{1 /(n+1)}
$$

Pour les canaux paraboliques l'équation devient :

$$
\left(\frac{d_{2}}{d_{1}}\right)=\left(\frac{5}{3}{\mathfrak{H}_{1}{ }^{2}}^{0,4}\right.
$$

qui peut aussi être employée comme première approximation de l'équation plus exacte si le rapport $\left(d_{2} / d_{1}\right)$ n'est pas élevé.

M. H. Diskrn,

\section{NOTRE FRONTISPICE}

(Cf. page 442)

EDISON (1847-1931)

Edison fut moins un savant, au sens conventionnel du terme qu'un remarquable observateur et un inventeur d'une fécondite extraordinaire.

Enfant, il fut tenu pour mauvais élève : a we cervelle creuse stupide, inapte a l'ecole $\$$, disaient ses maittes, parce qu'il posait trop de questions... De fait, il afficha toujours un certain mépri des mathematiques et leur prefera l'expérimentation; pendant qu'un de ses collaborateurs noircissait du papier durant plusieurs jours pour trouver le volume interne d'une ampoule de lampe électrique, Edison l'emplit simplement d'eau qu'il mesura ensuite

Doué d'un rare esprit d'observation, il passa maitre dans l'art d'expérimenter; avide de s'instruire, dévorant dès ses huit an des ouvrages d'histoire et de sciences, travaillant et réféchissant sans cesse ( Une heure passee a dormir est une heure perdue, j'ai tant de choses à faire et la vie est si courte $w$, disait-il) il en vint à détenir un étrange sawoir qu'll mit au service d'une énergie pelt commune et d'une activité exceptionnelle pout effec tuer une foule d'expériences qui devaient le conduire à de belles découvertes: télégraphie en duplex, microtéléphone, phonographe, éclairage électrique, machines, accumulateur alcalin au fer-nickel, etc. etc.

Né à Milan (Ohio) sur la rivière Huron le 11 février 1847 , Thomas Alva Edison conmença sa carrière à douze ans comm vendeur de journaux, bonbons et fruits dans les wayons du

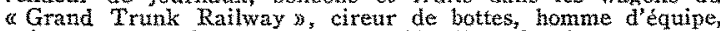
puis, ayant appris seul la typographie, il se fit rédacteur, compositenr et imprimeur - dans le fourgon du train - dur feuille de nouvelles gu'il vendait aux voyageurs.

En 1862, il devint télégraphiste et peu aprè̀s, il brevetait le système duplex dont la vente à un prix inespéré le sortit de la médiocrité ờ il vivait

Et co fut alors, pendant soixante années, une véritable floraison d'inventions, dans les domaines les plus divers et les plus inattendus.

A ses dons d'inventeur, Edison joignait des qualités morales de force de caractère, courage, opiniâtreté, désintéressement, goût du mouvement et de l'aventure, qui firent de cet homme, que sa profonde surdité n'empêchait pas d'être un bon musicien, un personnage fort attachant.

Edison mourut, comblé d'honneurs, à West Orange (N.T.) le 18 octobre 1931 .
EDISON (1847-1931)

The conventional image of the scientist sits wneasily upon Eation; it is jostlid aside by his outstanding acmity of observafion and his probinc inventweness.

As a child he was considered a bad pupil, his teachers fonding him "a dill, empty head, unteachable", because he asked too many anestions. Ho indeet betrayed an nnvarying contennt for thathentics, preforring practical experiment and whilst for mathematics, prefoning practical experiment and whilst intornal volume of an elcctric light bilb, Edison morely flled it with water, which he thert measured!

Gifted with rave powers of observation, he became a master in the art of practical experiment; oreedy for learting, from the the at of practical experment; greedy for learning, from the age of eight ontutads devotring histortcal and scietunc works, cd: "An hour aslees is ant hour thrown away; I have so much to do und life is short"). His efforts were rewarded by the mastery of a vast hotchyotch of ktrowledge ahich he harnessed to his abnormal energy and trilly remarkable capacity for reork, to cary ort the inn to cary ant the innimerable cxperiments which bore frit in stam fore inte

Born in Milan, Oho, on the Hurow River, on February 11th, 1847, Thamas Alva Edisont begant his carear at the agye of hwelve, as a newespaper boy-cum-frut and sweet seller, on the Grand Trminh Rathay. A ter being a boothiack and a navoy, he taught thimself typography and set himself up, in a railway liggage van, as editor, compositor and printer of a news sheet which he sold

In 1862, he became a telegraphist and soon aftorwards, patented the tworzay system, thanks to the incredible commercial success of which he was able to say goodbye to his down-at-hecl cxistence. This marked the beginning of sixty years of intense inventive activity in the most varied and wespected fields.

Eatison's inventive genius twas solidly braced by the aualities of force of character, courage, tenacity, disinterestedness, restless enargy and the taste for adventure; in short, a man (woho, th passtng, never let his aimost total deafness impair his musician. ship), from whom we find it hard to withhold our admiration. Edison died, full of years and honour, an October 18th 1931, at 